Article

\title{
Application of a Bacteriophage-Sanitizer Combination in Post-Harvest Control of E. coli O157:H7 Contamination on Spinach Leaves in the Presence or Absence of a High Organic Load Produce Wash
}

\author{
Badrinath Vengarai Jagannathan ${ }^{1}$, Steven Kitchens ${ }^{2}$, Stuart Price ${ }^{2}$, Melissa Morgan ${ }^{1}$ \\ and Paul Priyesh Vijayakumar ${ }^{1, *(D)}$ \\ 1 Department of Animal and Food Sciences, University of Kentucky, Lexington, KY 40456, USA; \\ badrivj@uky.edu (B.V.J.); melissa.morgan@uky.edu (M.M.) \\ 2 Department of Pathobiology, College of Veterinary Medicine, Auburn University, Auburn, AL 36849, USA \\ srk0002@auburn.edu (S.K.); pricesb@auburn.edu (S.P.) \\ * Correspondence: paul.v@uky.edu; Tel.: +1-859-257-1546; Fax: +1-859-257-5318
}

Citation: Vengarai Jagannathan, B.; Kitchens, S.; Price, S.; Morgan, M.; Vijayakumar, P.P. Application of a Bacteriophage-Sanitizer Combination in Post-Harvest Control of E. coli O157:H7 Contamination on Spinach Leaves in the Presence or Absence of a High Organic Load Produce Wash. Appl. Microbiol. 2022, 2,12-24. https://doi.org/10.3390/ applmicrobiol2010002

Academic Editor: Lucía Fernández

Received: 22 November 2021

Accepted: 13 December 2021

Published: 27 December 2021

Publisher's Note: MDPI stays neutral with regard to jurisdictional claims in published maps and institutional affiliations.

Copyright: (C) 2021 by the authors. Licensee MDPI, Basel, Switzerland. This article is an open access article distributed under the terms and conditions of the Creative Commons Attribution (CC BY) license (https:// creativecommons.org/licenses/by/ $4.0 /)$.

\begin{abstract}
Foodborne illness due to the consumption of contaminated products continues to be a serious public health issue. Bacteriophages might provide a natural and effective way to control and reduce the pathogenic bacterial population on food products. Researchers have conducted various experiments to prove their effectiveness against different pathogens and their ability to act as a natural intervention to control pathogen populations, especially in the food industry. In this study, a cocktail of bacteriophages (phages) was added to wash water in the presence of a high organic load along with commercially used sanitizers (chlorine or Sanidate 5.0) to study the efficacy of the phage-sanitizer combination in the challenge water. It was determined that in the absence of organic loads, the sanitizer by itself or the combination with phages significantly $(p<0.001)$ reduced the contamination by 3.00-5.00 $\log \mathrm{CFU} / \mathrm{mL}$. In the presence of organic loads, the sanitizer by itself did not contribute to a significant reduction $(p>0.05)$ compared to the control. However, the sanitizer-phage combination led to a 3.00-log and 6.00-log reduction $(p<0.001)$ of the pathogen at the end of 3 and $6 \mathrm{~h}$, respectively, in the presence of high organic loads. Therefore, utilizing a combination treatment (phage-sanitizer) might be one solution to reduce pathogen contamination in the food industry, especially the fresh produce industry, thus providing safe food for consumption.
\end{abstract}

Keywords: E. coli O157:H7; produce wash; sanitizer; organic load; bacteriophage

\section{Introduction}

Consumption of fresh fruits and vegetables continues to increase in the United States due to its association with a healthy lifestyle [1]. Fresh produce remains one of the leading causes of foodborne illness due to contamination with various pathogens such as Salmonella, Listeria monocytogens, and Shiga-toxin-producing Escherichia coli [1]. A significant portion of the produce is consumed raw, and the number of outbreaks associated with it has shown their ability to act as a vehicle to spread pathogenic bacteria. The open nature of how raw produce is handled in the food supply chain implies that the contamination can be introduced at any point during production, harvest, and processing [2]. Hence, disinfecting produce after harvesting is considered an essential step for the post-harvest handling of fruits and vegetables [3]. The minimum requirement for a produce-handling facility is to have a disinfection procedure that ensures the commodity is free from fungal and bacterial pathogens [3]. This is usually achieved using disinfectants such as chlorine, chlorine dioxide, ozone, ethanol, hydrogen peroxide, organic acids, and electrolyzed water [3]. In 2019, a foodborne outbreak of E. coli O157:H7 was linked to the consumption of romaine lettuce produced from the Salinas Valley growing region in California [4]. The outbreak 
resulted in 167 infections and 85 hospitalizations. An outbreak of Salmonella carriage linked to pre-cut melon consumption left 137 people infected and required 38 hospitalizations in the United States [4]. The rise in foodborne outbreaks in recent years has made the regulatory agencies, the producers, and the public increasingly concerned regarding the microbial safety of fresh fruits and vegetables [5]. Washing is defined as rinsing, scrubbing, rubbing, or dipping produce to remove any field-acquired contamination from the produce's surface [6]. Washing produce is primarily done to improve physical appearance and reduce any microbial or chemical residues that can hasten spoilage, cause product recalls, or result in human illness [6]. Immersion washers are widely used techniques for washing produce such as melons, tomatoes, cucumbers, and loose greens [6]. Dunk tank immersion washers are mainly employed to remove large debris and biological contaminants and to reduce physical impact and tissue damage. One significant safety issue with the dunk tank technique of produce washing is the infiltration of water into produce, especially when warm produce is dunked in cold water [6,7]. Various factors such as temperature, depth of water, soaking time, wound/scarring, and maturity of the products have to be considered to avoid the cross-contamination or infiltration of contaminated water [7]. These washers also use recirculated water, which adds increasing organic loads such as debris, soil particles, and other exudates from processed produce tissue [8]. It was previously assumed that post-harvest washing/sanitation with antimicrobials was adequate to clean/sanitize produce and prevent the possibility of potential cross-contaminants [3,9]. However, recent outbreaks and subsequent research have shown that post-harvest washing under commercial conditions has limited efficacy in the decontamination of produce and might even lead to the cross-contamination of produce during the wash step $[10,11]$.

In our previous works, we studied the effect of the bacteriophages on the pathogen E. coli O157:H7 and also their ability to survive $100 \mathrm{ppm}$ sanitizer (bleach and Sanidate 5.0) [12]. We also demonstrated their ability to infect the pathogen selectively in the presence of high organic loads. We wanted to further extend this work to see how a combination treatment (bacteriophage-sanitizer) would benefit in reducing contamination [13]. Thus, the focus of this research is to investigate the ability of bacteriophages to reduce E. coli O157:H7 contamination on baby spinach in the presence or absence of an organic load along with 100-ppm bleach or Sanidate 5.0 (hydrogen peroxide and peroxyacetic acid; a commercially used organic sanitizer).

\section{Materials and Methods}

\subsection{Bacterial Culture for Microplate and Produce Wash Study}

Pathogenic Escherichia coli O157:H7 (ATCC 35150) was obtained from freezer stock. Working stock cultures were prepared by resuspending cells into tryptic soy broth (TSB, Difco, Becton-Dickenson Labs, Hunt Valley, MD, USA) and incubated for $48 \mathrm{~h}$ at $37{ }^{\circ} \mathrm{C}$ before streaking the cultures on MacConkey Agar (MAC, Difco, Becton-Dickenson Labs) and Sorbitol MacConkey Agar (SMAC, Derry, NH, USA, Difco) for isolation. After incubation for $24 \mathrm{~h}$ at $37^{\circ} \mathrm{C}$, the characteristics of the colonies were observed, and individual colonies were picked from SMAC into TSB tubes (supplemented with $5 \mathrm{mM}$ of magnesium sulfate $\left(\mathrm{MgSO}_{4}\right.$, Fisher Scientific, Branchburg, NJ, USA) and calcium chloride $\left(\mathrm{CaCl}_{2}\right.$, Fisher Scientific, Branchburg, NJ, USA)) using a sterile technique. Cultures were grown on tryptic soy agar (TSA, Difco, Becton-Dickenson Labs, Hunt Valley, MD, USA) for $24 \mathrm{~h}$ at $37^{\circ} \mathrm{C}$ and then stored at refrigeration temperature $4{ }^{\circ} \mathrm{C}$ until needed for propagation.

\subsection{Bacteriophage Cocktail Preparation}

Four bacteriophages (C14s, V9, L1, and LL15), specific to E. coli O157:H7, were obtained from bovine feces [12]. The bacteriophages were isolated and characterized by the Auburn University College of Veterinary Medicine. Bacteriophages were individually grown for $24 \mathrm{~h}$ at $37^{\circ} \mathrm{C}$ in Luria-Bertani broth (LB) with host E. coli O157:H7. Phages were separated via centrifugation at 20,000 rpm for $20 \mathrm{~min}$ in the presence of chloroform. The phages were then filter-sterilized through a $0.22 \mu \mathrm{m}$ filter (Miller-Gs, Aurachtal, Germany) into 
working stock containers(Corning Science, Reynosa, Mexico). A bacteriophage titer was determined to confirm phage activity. The host strain for all the bacteriophages was E. coli O157:H7 (ATCC 35150). An agar overlay method was used to determine the titer for the bacteriophages against the host. Phage cocktail titer was approximately $10^{9}$ plaque-forming units (PFUs) $/ \mathrm{mL}$ for the phage cocktail, tested every time before the study [12]. Equal numbers $(1 \mathrm{~mL})$ of individual bacteriophage types were mixed in a sterile test tube, and the required volume was pipetted right before every experiment to make the phage cocktail.

\subsection{Initial Produce Rinse to Reduce Background Microbial Contamination on Spinach Leaves}

Fresh baby spinach leaves were purchased from a local grocery chain. Spinach leaves (25 leaves) were transferred into a sterile filter bag (Fisher brand blender bags) and treated with $200 \mathrm{~mL}$ of $2 \%$ lactic acid solution (Fisher Scientific) for $15 \mathrm{~min}$. The leaves were then transferred to a new bag and treated with $200 \mathrm{~mL}$ of 100-ppm bleach water (Clorox, Oakland, CA, USA) for $15 \mathrm{~min}$. A lactic acid and chlorine wash was performed to help with reducing the background microbial population. Leaves were then exposed to UV light (Germicidal UV lamp, $30 \mathrm{~W}$ and $893 \mathrm{~mm}$ ) (Ushio, Parker, CO, USA) inside the laminar hood for $15 \mathrm{~min}$ to reduce the background population of microorganisms and dissipate any residual chlorine present on the leaves. Negative control (NC) samples were collected after the initial rinse to analyze whether the wash successfully reduced the background flora.

\subsection{Wash Solution for the Simulated Dunk Tank}

Wash solutions were made to simulate the produce industry's wash water. The first set of wash solutions was made with $20 \mathrm{~mL}$ of sterile doubled deionized water containing 100-ppm bleach (Treatment 1 or Trt.1) and 100-ppm Sanidate 5.0 (Treatment 2 or Trt.2). These washes were used to determine their effect against $E$. coli O157:H7 and their efficacy with the addition of the phage cocktail to each disinfectant, respectively (Treatment 3 (Trt.3) and Treatment 4 (Trt.4)) (Figure 1). Positive control (PC) samples were treated similarly with water and E. coli O157:H7. In all the treatments, the samples were completely immersed in the wash solution for the full contact time of $10 \mathrm{~min}$, and the study was repeated three times.

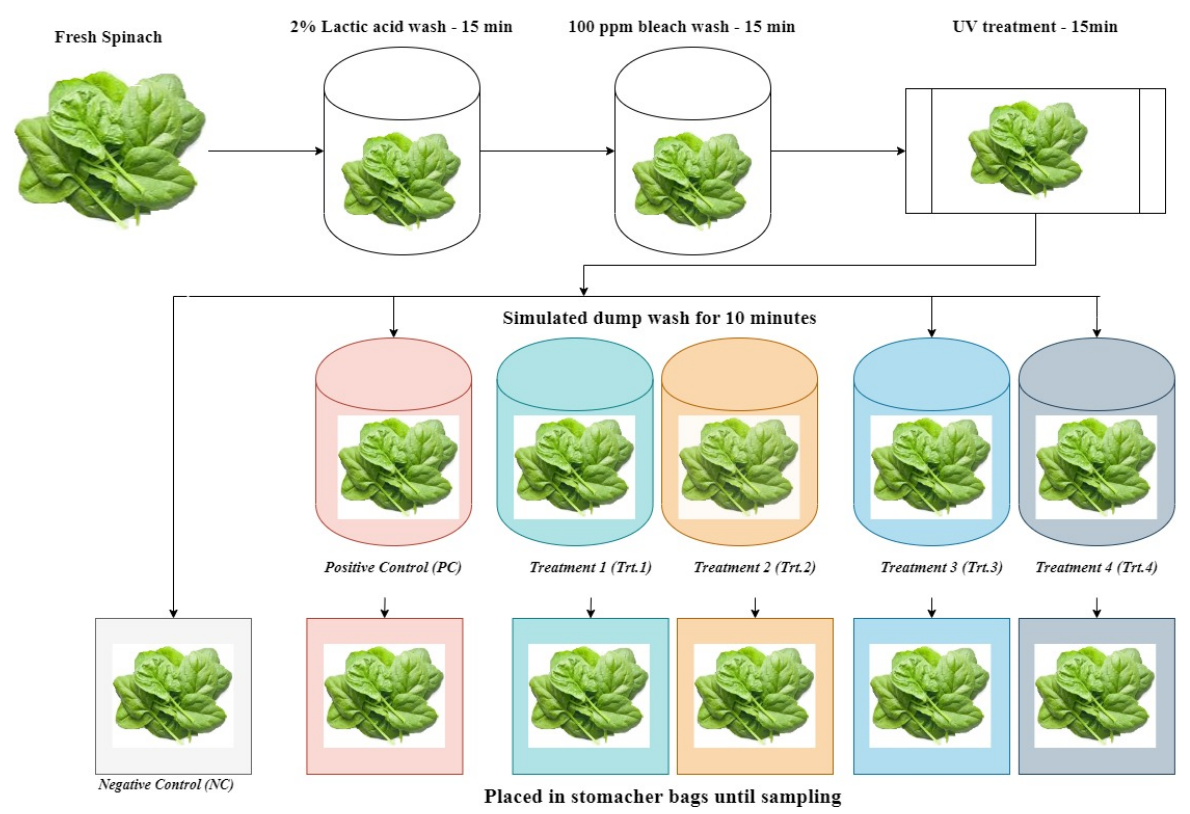

Figure 1. Schematic flow of initial produce rinse and dunk wash of spinach in sterile water combined with the sanitizer and bacteriophage cocktail. NC-No treatment, PC-Leaves washed with E. coli O157:H7, Trt.1—Leaves washed with E. coli O157:H7 in water containing 100-ppm bleach, Trt.2Leaves washed with E. coli O157:H7 in water containing 100-ppm Sanidate 5.0, Trt.3-Leaves washed with E. coli $\mathrm{O} 157: \mathrm{H7}$ in water containing the 100-ppm bleach and phage cocktail, Trt.4-Leaves washed with E. coli O157:H7 in water containing the 100-ppm Sanidate 5.0 and phage cocktail. 


\subsection{Wash Solution for the Simulated Dunk Tank with High Organic Load Water}

Wash solutions were made similarly with 100-ppm bleach (Treatment 1 or Trt O.1) and 100-ppm Sanidate 5.0 (Treatment 2 or Trt O.2) in $20 \mathrm{~mL}$ of sterilized DE broth (DeyEngley neutralizing broth) containing approximately $9810-\mathrm{ppm}$ of dissolved organic matter (casein-1660-ppm, yeast extract-830-ppm, dextrose-3330-ppm, Tween 80-1660-ppm, and lecithin-2330-ppm). These washes were used to determine the effect of the sanitizers against the pathogen and the addition of the phage cocktail (Treatment (Trt O.3) and Treatment 4 (Trt O.4)) to infect E. coli O157:H7 in the presence of high organic loads (Figure 2). Negative-control samples (NCO) were treated similarly with organic load wash water without the bacteriophage cocktail. In all the treatments, the samples were completely immersed in the wash solution for the full contact time of $10 \mathrm{~min}$, and the study was repeated three times.

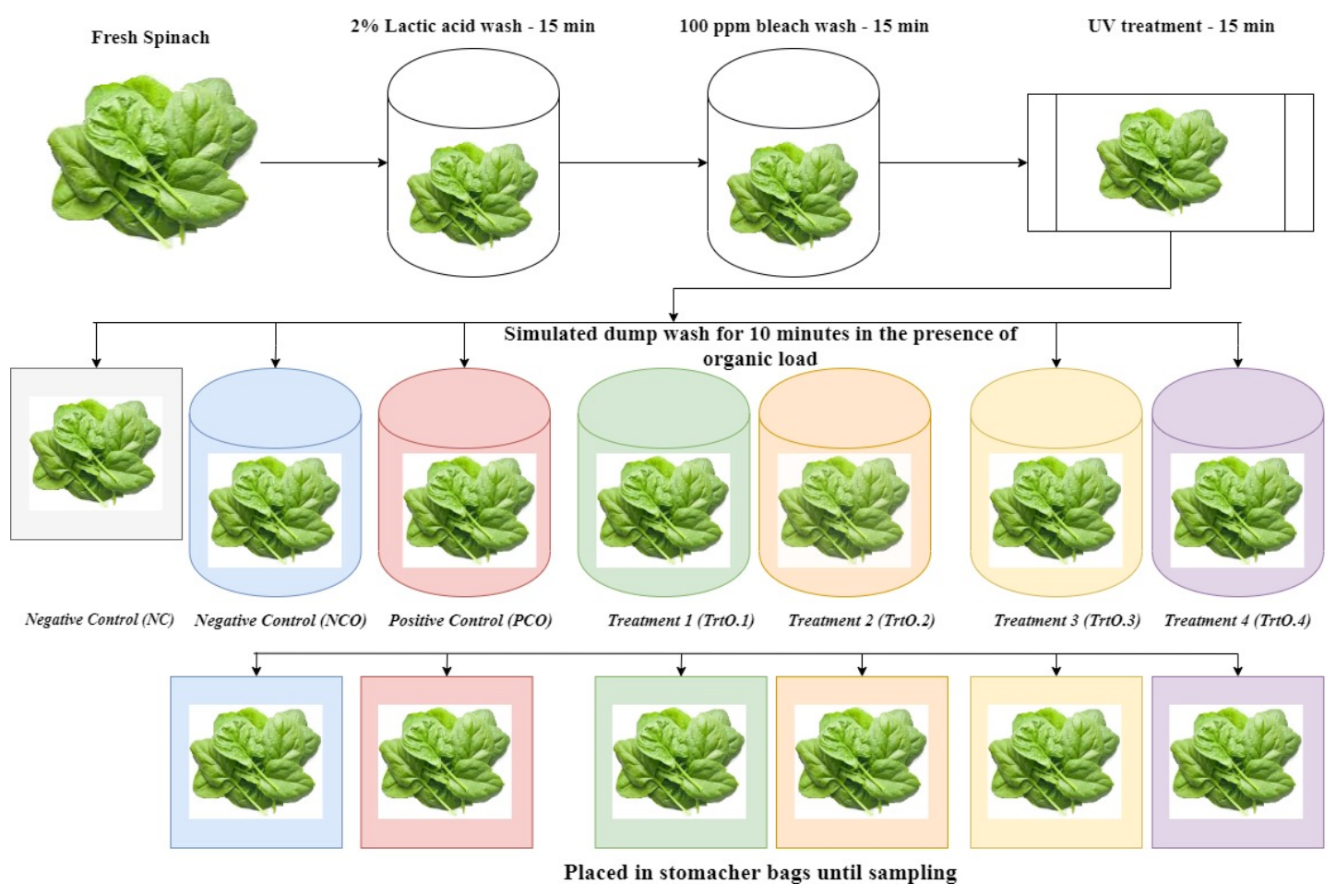

Figure 2. Schematic flow of initial produce rinse and dunk wash of spinach in high organic load water combined with the sanitizer and bacteriophage cocktail. NC—No treatment, NCO-Leaves washed in high organic load water, PCO_Leaves washed in organic water containing E. coli O157:H7, Trt.O.1-Leaves washed in organic water containing E. coli O157: H7 + volume of bleach to contribute 100-ppm, Trt.O.2-Leaves washed in organic water containing E. coli O157: H7 + volume of Sanidate 5.0 to contribute 100-ppm, Trt.O.3-Leaves washed in organic water containing E. coli O157: H7 + volume of bleach to contribute a 100-ppm and phage cocktail, Trt.O.4-Leaves washed in organic water containing E. coli O157: H7 + volume of Sanidate 5.0 to contribute a 100-ppm and phage cocktail.

\subsection{Application of Wash Solution Containing E. coli O157:H7 and Bacteriophage Cocktail Treatment in a Simulated Dunk Tank}

Fresh spinach leaves, after the initial produce-rinse step, were separated into six different treatments: negative control (NC), positive control (PC), 100-ppm bleach treatment (Trt.1), 100-ppm Sanidate 5.0 treatment (Trt.2), 100-ppm bleach + bacteriophage cocktail treatment (Trt.3), and 100-ppm Sanidate 5.0 + bacteriophage cocktail treatment (Trt.4) (Figure 1). The NC was pre-rinsed spinach without any other treatment to validate the initial wash's efficacy and to observe if any background microorganisms were still present on the leaves. The PC sample had leaves that were dunk-washed for $10 \mathrm{~min}$ in $20 \mathrm{~mL}$ sterile potable water containing $1500 \mu \mathrm{L}$ of E. coli O157:H7 $\left(\sim 1.0 \times 10^{9} \mathrm{CFU} / \mathrm{mL}\right)$. Trt.1 and 
Trt.2 were similar to PC, but the leaves were dunked in $100 \mathrm{ppm}$ concentration sanitizer along with the pathogen. Trt. 3 samples had leaves dunk-washed in $20 \mathrm{~mL}$ sterile potable water containing 100-ppm bleach along with a combination of $1500 \mu \mathrm{L}$ of E. coli O157:H7 $\left(\sim 1.0 \times 10^{9} \mathrm{CFU} / \mathrm{mL}\right)$ and $3000 \mu \mathrm{L}$ of the bacteriophage cocktail (MOI: 3$)$. The Trt.4 samples were treated similarly to Trt.3 but with 100-ppm Sanidate 5.0. All the samples, after processing, were placed in a sterile sampling bag at room temperature and sampled at 0,3 , and $6 \mathrm{~h}$.

\subsection{Application of Wash Solution with High Organic Load Containing E. coli O157:H7 and Bacteriophage Cocktail Treatment in a Simulated Dunk Tank}

A similar procedure from the above study was utilized with DE broth instead of potable water to mimic the organic loads present in the wash water. The controls and treatments for this experiment are represented as NCO, PCO, Trt.O.1, Trt.O.2, Trt.O.3, and Trt.O.4, respectively (Figure 2).

\subsection{Recovery of Bacteria}

A random leaf was picked from each treatment and rinsed with $1 \mathrm{~mL}$ sterile phosphate buffer. Samples were held at room temperature and massaged through the sampling bag for one minute. Serial dilutions of the sample rinse were made in phosphate buffer ( $\mathrm{pH}$ 7.4-7.5). The dilutions were then plated on pre-made TSA plates and supplemented with $5 \mathrm{mM}$ magnesium sulfate $\left(\mathrm{MgSO}_{4}\right.$, Fisher Scientific) and $5 \mathrm{mM}$ calcium chloride $\left(\mathrm{CaCl}_{2}\right.$, Fisher Scientific).

\subsection{Statistical Analysis}

Separate linear mixed models for the sterile and organic rinse experiments were used to analyze the response of log value with respect to treatment, time (hours 3 and 6), and the interaction of treatment and time. Random effects for the subject and date were initially included in both models, but this resulted in zero variance estimates for random effects. For each rinse, the models were fitted again twice-once with just the subject random effect and once with just the date random effect. For the sterile rinse, the subject model had a random effect variance estimate of 0 again and the date model did not; therefore, the date model was selected as the final model. For the organic rinse, both models had valid non-zero random effect variance estimates, so the model with lower AIC was selected —-the subject model. Tukey's method for multiple comparisons was used to test pairwise differences between treatment effects. All analyses were conducted using the lme4 [14], lmerTest [15], and emmeans [16] packages in R 4.0.2 (R Core Team 2020).

\section{Results}

3.1. Effect of Bacteriophage Cocktail in Sterile Water Wash Solution Containing E. coli O157:H7 in a Simulated Dunk Tank with 100-ppm Bleach

The initial produce rinse successfully inhibited the growth of background flora on fresh spinach leaves. The plate count $(<1.00 \log \mathrm{CFU} / \mathrm{mL})$ on the NC indicated that the initial rinse effectively reduced the background microflora. Table 1 shows the efficacy of 100-ppm bleach and the 100-ppm bleach/bacteriophage cocktail combination in reducing E. coli O157:H7 on spinach compared to the control wash. The 10 min contact time for the wash solution resulted in a significant reduction $(p<0.001)$ of the pathogen at the end of $3 \mathrm{~h}$ in both the treatments compared to the PC. The 100-ppm bleach treatment by itself contributed to a $3.13 \log \mathrm{CFU} / \mathrm{mL}(99.87 \%)$ reduction at the end of $3 \mathrm{~h}$, and this was maintained until the end of $6 \mathrm{~h}$ despite some recovery. Since there was a parallel increase in the PC at $6 \mathrm{~h}$, the pathogen numbers' gradual recovery in Trt. 1 still reflected $3.00 \log$ CFU $/ \mathrm{mL}$ at the end of $6 \mathrm{~h}$. In the case of leaves washed with the sanitizer-bacteriophage combination, there was a $5.51 \log \mathrm{CFU} / \mathrm{mL}(99.99 \%)$ reduction at the end of $3 \mathrm{~h}$, which was maintained until the end of $6 \mathrm{~h}$. Similar to Trt.1, Trt.3 reflected a gradual recovery, but a parallel increase to the PC maintained the $5.00 \log \mathrm{CFU} / \mathrm{mL}$ reduction at the end of $6 \mathrm{~h}$. The statistical analysis indicated that despite the recovery, the treatments were significantly different from the PC. 
Therefore, the disinfectant treatments (Trt.1 and Trt.3) were significantly effective $(p<0.001)$ in reducing the population of E. coli O157:H7 on the spinach leaves compared to the PC (Figure 3A).

Table 1. Reduction of E. coli O157:H7 (ATCC 35150) on spinach via post-harvest pathogen control measures using a bacteriophage cocktail in combination with a commercially used sanitizer wash solution made with potable water in a simulated dunk tank. The mean and standard deviation (SD) were calculated from triplicate replication. Estimated marginal means and standard error (SE) from the statistical model and Tukey groupings.

\begin{tabular}{|c|c|c|c|c|c|c|}
\hline Wash Treatment & $\begin{array}{l}\text { Wash } \\
\text { Time } \\
\text { (min) }\end{array}$ & $\begin{array}{l}\text { Sampling } \\
\text { Time } \\
\text { (h) }\end{array}$ & $\begin{array}{l}\text { E. coli } 0157: \mathrm{H7} \\
\text { Population (log } \\
\text { CFU/mL (SD)) }\end{array}$ & $\begin{array}{l}\text { Estimated } \\
\text { Marginal } \\
\text { Mean (SE) }\end{array}$ & $\begin{array}{c}\text { E. coli } \\
\text { O157:H7 Log } \\
\text { Reduction } \\
(\log \text { CFU/mL) }\end{array}$ & $\begin{array}{c}\text { Percentage } \\
\text { Reduction }(\%) \text { of } \\
\text { E. coli } \mathrm{O} 157: \mathrm{H7} \\
\text { Compared to PC }\end{array}$ \\
\hline $\begin{array}{l}\text { Negative Control } \\
\text { (NC) }\end{array}$ & - & $\begin{array}{l}0 \\
3 \\
6\end{array}$ & $\begin{array}{l}<1.00 \\
<1.00 \\
<1.00\end{array}$ & - & - & - \\
\hline $\begin{array}{l}\text { Positive Control } \\
\text { (PC) }\end{array}$ & 10 & $\begin{array}{l}0 \\
3 \\
6\end{array}$ & $\begin{array}{l}6.43(0.16) \\
6.62(0.47) \\
7.42(0.29)\end{array}$ & $7.02(0.14)^{a}$ & - & - \\
\hline $\begin{array}{c}\text { Treatment } 1-100-p p m \\
\text { bleach water } \\
\text { (Trt.1) }\end{array}$ & 10 & $\begin{array}{l}0 \\
3 \\
6\end{array}$ & $\begin{array}{l}3.24(0.28) \\
3.49(0.30) \\
4.04(0.73)\end{array}$ & $3.77(0.14)^{b}$ & $\begin{array}{l}3.19 \\
3.13 \\
3.38\end{array}$ & $\begin{array}{l}99.86 \\
99.87 \\
99.85\end{array}$ \\
\hline $\begin{array}{l}\text { Treatment } 2-100-p p m \\
\text { Sanidate } 5.0 \text { water (Trt.2) }\end{array}$ & 10 & $\begin{array}{l}0 \\
3 \\
6\end{array}$ & $\begin{array}{l}<1.00 \\
<1.00 \\
<1.00\end{array}$ & $0.00(0.14)^{d}$ & $\begin{array}{l}6.43 \\
6.62 \\
7.42\end{array}$ & $\begin{array}{l}99.99 \\
99.99 \\
99.99\end{array}$ \\
\hline $\begin{array}{c}\text { Treatment } 3-100-\text { ppm bleach } \\
\text { water + bacteriophage cocktail } \\
\text { (Trt.3) }\end{array}$ & 10 & $\begin{array}{l}0 \\
3 \\
6\end{array}$ & $\begin{array}{l}4.35(0.25) \\
1.11(0.21) \\
2.10(0.16)\end{array}$ & $1.61(0.14)^{c}$ & $\begin{array}{l}2.08 \\
5.51 \\
5.32\end{array}$ & $\begin{array}{l}98.26 \\
99.99 \\
99.99\end{array}$ \\
\hline $\begin{array}{c}\text { Treatment } 4-100-p p m \text { Sanidate } \\
5.0 \text { water }+ \text { bacteriophage } \\
\text { cocktail (Trt. } 4 \text { ) }\end{array}$ & 10 & $\begin{array}{l}0 \\
3 \\
6\end{array}$ & $\begin{array}{l}<1.00 \\
<1.00 \\
<1.00\end{array}$ & $0.00(0.14)^{d}$ & $\begin{array}{l}6.43 \\
6.62 \\
7.42\end{array}$ & $\begin{array}{l}99.99 \\
99.99 \\
99.99\end{array}$ \\
\hline
\end{tabular}

${ }^{\mathrm{a}-\mathrm{d}}$ Represents the difference in significance between the results.

3.2. Effect of Bacteriophage Cocktail in Sterile Water Wash Solution Containing E. coli O157:H7 in a Simulated Dunk Tank with 100-ppm Sanidate 5.0

The initial produce rinse successfully inhibited the growth of background flora on fresh spinach. The plate count $(<1.00 \log \mathrm{CFU} / \mathrm{mL})$ on the NC indicated that the initial rinse effectively reduced the background microflora. Table 1 shows the bacteriophage cocktail's efficacy in the reduction of E. coli O157:H7 on spinach washed in water containing 100 -ppm Sanidate 5.0 along with the phage cocktail compared to the control wash. The 10 min contact time for the wash solution resulted in a significant reduction $(p<0.001)$ of the pathogen at the end of $3 \mathrm{~h}$ compared to the PC in both the treatments. Recovery of the pathogen was not observed in both the treatments at 0,3 and $6 \mathrm{~h}$. The statistical analysis indicated that both treatments (Trt.2 and Trt.4) were significantly different from the PC. Therefore, treatments Trt. 2 and Trt. 4 were significantly effective $(p<0.001)$ in reducing the population of E. coli O157:H7 on the spinach leaves (Figure 3B). 

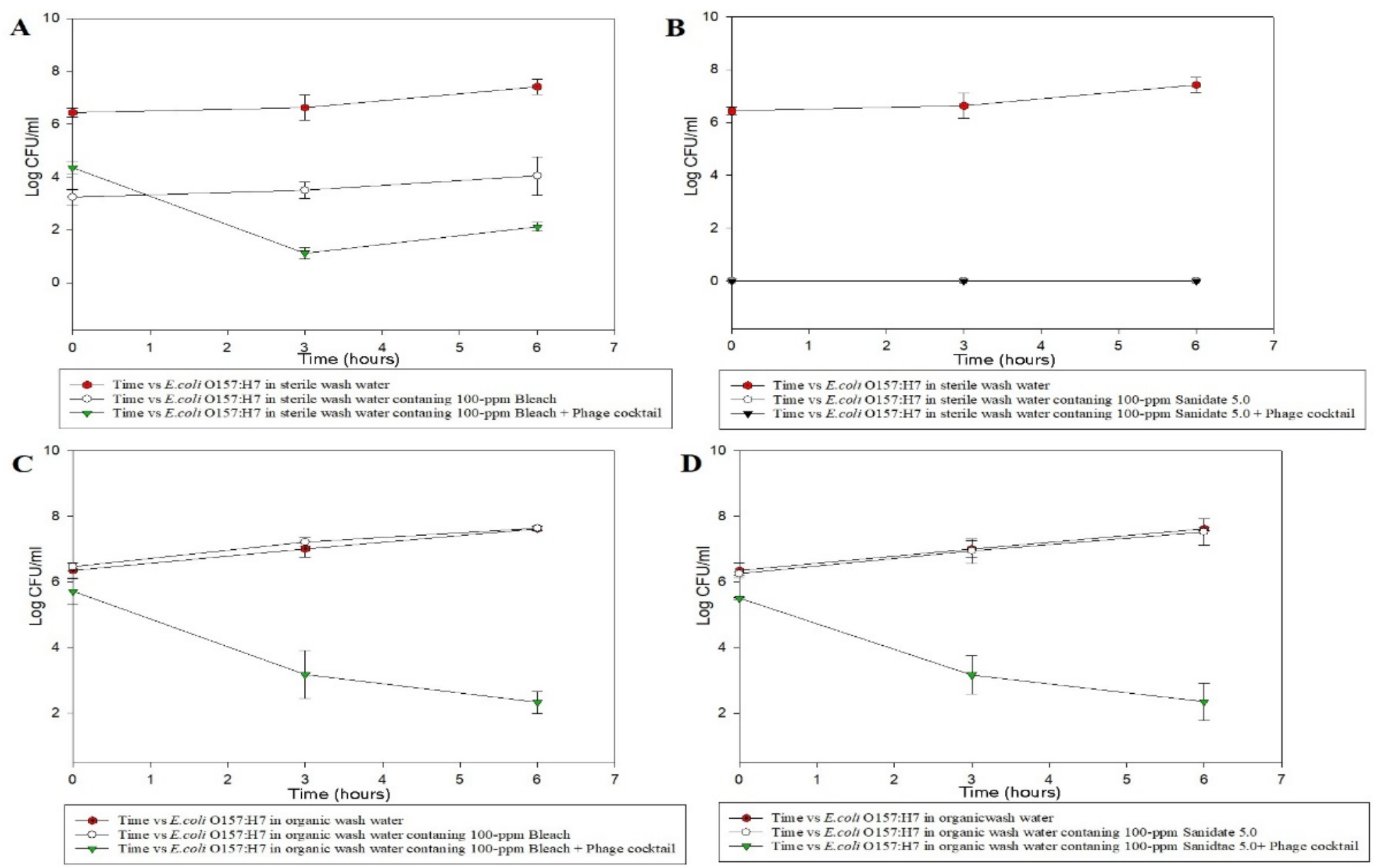

Figure 3. Reduction of E. coli O157:H7 contamination of spinach leaves treated with a bacteriophage cocktail in combination with sanitizer. (A) 100-ppm bleach and 100-ppm bleach + bacteriophage cocktail in sterile wash water, (B) 100-ppm Sanidate 5.0 and 100-ppm Sanidate $5.0+$ bacteriophage cocktail in sterile wash water (multiple data points overlapping), (C) 100-ppm bleach and 100-ppm bleach + bacteriophage cocktail in high organic wash water, (D) 100-ppm Sanidate 5.0 and 100-ppm Sanidate $5.0+$ bacteriophage cocktail in high organic wash water. The data points represent the means of triplicate replication, and the error bars represent the standard deviations of three independent experiments. 
3.3. Effect of Sterile Wash Solution Containing 9810 ppm of Organic Load Comprising E. coli 0157:H7 and Bacteriophage Cocktail Treatment in a Simulated Dunk Tank with 100-ppm Bleach

The initial produce rinse was once again effective in reducing the spinach's background microflora $(<1.00 \log \mathrm{CFU} / \mathrm{mL})$. The secondary negative control (NCO) also had no recovery $(<1.00 \mathrm{CFU} / \mathrm{mL})$ on the studies, which indicated that the organic load did not influence the growth of any underlying microflora. Table 2 shows the bacteriophage cocktail's efficacy in the reduction of E. coli O157:H7 on spinach washed in the challenge water (9810 ppm organic load) containing the phage cocktail compared with the control wash. The $10 \mathrm{~min}$ contact time for the wash solution resulted in a significant reduction $(p<0.001)(99.96 \%$ and $99.99 \%$ ) of the pathogen at the end of 3 and $6 \mathrm{~h}$. Compared to Trt.O.1 and the PC, the bacteriophage treatment (Trt.O.3) resulted in reductions of $3.83 \log$ and $5.30 \log \mathrm{CFU} / \mathrm{mL}$ at the end of 3 and $6 \mathrm{~h}$, respectively. In Trt.O.1, the obtained data were not significantly different from the PC, and the pathogen had a similar growth pattern. This study illustrates the bacteriophage's specificity and its ability to effectively reduce E. coli O157:H7 despite being in an environment with a high organic load (Figure 3C).

Table 2. Reduction of E. coli O157:H7 (ATCC 35150) on spinach via post-harvest pathogen control measures using a bacteriophage cocktail in combination with a commercially used sanitizer wash solution made with high organic load water in a simulated dunk tank. The mean and standard deviation (SD) were calculated from triplicate replication. Estimated marginal means and standard error (SE) from the statistical model and Tukey groupings.

\begin{tabular}{|c|c|c|c|c|c|c|c|c|}
\hline Wash Treatment & $\begin{array}{l}\text { Wash } \\
\text { Time } \\
\text { (min) }\end{array}$ & $\begin{array}{l}\text { Sampling } \\
\text { Time (h) }\end{array}$ & $\begin{array}{c}\text { E. coli } \\
\text { O157:H7 } \\
\text { Population } \\
\text { (log } \\
\text { CFU/mL } \\
\text { (SD)) }\end{array}$ & $\begin{array}{l}\text { Estimated } \\
\text { Marginal } \\
\text { Mean (SE) }\end{array}$ & $\begin{array}{c}\text { E. coli } \\
\text { O157:H7 } \\
\text { Log } \\
\text { Reduction } \\
\text { (log } \\
\text { CFU/mL) }\end{array}$ & $\begin{array}{c}\text { Percentage } \\
\text { Reduction } \\
\text { (\%) of } \\
\text { E. coli } \\
\text { O157:H7 } \\
\text { Compared } \\
\text { to PC }\end{array}$ & $\begin{array}{c}\text { Percentage } \\
\text { Reduction } \\
\text { (\%) in } \\
\text { Trt.O.3 } \\
\text { Com- } \\
\text { pared to } \\
\text { Trt.O.1 }\end{array}$ & $\begin{array}{c}\text { Percentage } \\
\text { Reduction } \\
(\%) \\
\text { in Trt.O.4 } \\
\text { Compared } \\
\text { to Trt.O.2 }\end{array}$ \\
\hline $\begin{array}{c}\text { Negative Control } \\
\text { (NC) }\end{array}$ & - & $\begin{array}{l}0 \\
3 \\
6\end{array}$ & $\begin{array}{l}<1.00 \\
<1.00 \\
<1.00\end{array}$ & - & - & - & - & - \\
\hline $\begin{array}{c}\text { Negative Control } \\
\text { Organic } \\
(\mathrm{NCO})\end{array}$ & 10 & $\begin{array}{l}0 \\
3 \\
6\end{array}$ & $\begin{array}{l}<1.00 \\
<1.00 \\
<1.00\end{array}$ & - & - & - & - & \\
\hline $\begin{array}{c}\text { Positive Control } \\
\text { (PC) }\end{array}$ & 10 & $\begin{array}{l}0 \\
3 \\
6\end{array}$ & $\begin{array}{l}6.35(0.22) \\
7.00(0.25) \\
7.62(0.06)\end{array}$ & $7.32(0.21)^{\mathrm{a}}$ & - & - & - & - \\
\hline $\begin{array}{c}\text { Treatment } \\
\text { 1-100-ppm bleach in } \\
\text { organic water } \\
\text { (Trt.O.1) }\end{array}$ & 10 & $\begin{array}{l}0 \\
3 \\
6\end{array}$ & $\begin{array}{l}6.46(0.11) \\
7.20(0.12) \\
7.63(0.05)\end{array}$ & $7.43(0.21)^{\mathrm{a}}$ & $\begin{array}{l}\text { No } \\
\text { significant } \\
\text { reduction }\end{array}$ & $\begin{array}{l}09.66 \\
30.90 \\
38.97\end{array}$ & - & - \\
\hline $\begin{array}{c}\text { Treatment } \\
\text { 2-100-ppm Sanidate } \\
5.0 \text { in organic water } \\
\text { (Trt.O.2) }\end{array}$ & 10 & $\begin{array}{l}0 \\
3\end{array}$ & $\begin{array}{l}6.25(0.05) \\
6.94(0.37) \\
7.52(0.40)\end{array}$ & $7.24(0.21)^{\mathrm{a}}$ & $\begin{array}{l}0.10 \\
0.06 \\
0.10\end{array}$ & $\begin{array}{l}14.89 \\
43.27 \\
45.64\end{array}$ & - & - \\
\hline $\begin{array}{c}\text { Treatment } \\
\text { 3-100-ppm bleach in } \\
\text { organic water }+ \\
\text { bacteriophage } \\
\text { cocktail (Trt.O.3) }\end{array}$ & 10 & $\begin{array}{l}0 \\
3\end{array}$ & $\begin{array}{l}5.70(0.37) \\
3.17(0.72)\end{array}$ & $2.75(0.21)^{b}$ & $\begin{array}{l}0.65 \\
3.83\end{array}$ & $\begin{array}{l}57.12 \\
99.96\end{array}$ & $\begin{array}{l}63.29 \\
99.98\end{array}$ & - \\
\hline $\begin{array}{c}\text { Treatment } \\
\text { 4-100-ppm Sanidate } \\
5.0 \text { in organic water } \\
\text { + bacteriophage } \\
\text { cocktail (Trt.O.4) }\end{array}$ & 10 & $\begin{array}{l}0 \\
3\end{array}$ & $\begin{array}{l}5.50(0.03) \\
3.17(0.58)\end{array}$ & $2.76(0.21)^{b}$ & $\begin{array}{l}0.85 \\
3.83\end{array}$ & $\begin{array}{l}76.72 \\
99.97\end{array}$ & - & $\begin{array}{l}69.81 \\
99.96\end{array}$ \\
\hline
\end{tabular}

$\mathrm{a}, \mathrm{b}$ Represents the difference in significance between the results. 
3.4. Effect of Sterile Wash Solution Containing 9810 ppm of Organic Load Comprising E. coli O157:H7 and Bacteriophage Cocktail Treatment in a Simulated Dunk Tank with 100-ppm Sanidate 5.0

The initial produce rinse was once again effective in reducing the spinach's background microflora $(<1.00 \log \mathrm{CFU} / \mathrm{mL})$. Table 2 shows the bacteriophage cocktail's efficacy in the reduction of E. coli O157:H7 on spinach washed in the challenge water (9810-ppm organic load) containing the phage cocktail compared with the control wash. The 10 min contact time for the wash solution resulted in a significant reduction $(p<0.001)(99.97$ and 99.99\%) of the pathogen at the end of 3 and $6 \mathrm{~h}$. Compared to Trt.O.2 and the PC, the bacteriophage treatment (Trt.O.4) resulted in reductions of $3.83 \log$ and $5.27 \log$ CFU / $\mathrm{mL}$ at the end of 3 and $6 \mathrm{~h}$, respectively. In Trt.O.2, the obtained data were not significantly different from the PC, and the pathogen had a similar growth pattern. This study also illustrates the bacteriophage's specificity and its ability to effectively reduce E. coli O157:H7 despite being in an environment with a high organic load (Figure 3D).

Increased microbial contamination in produce has led to several foodborne outbreaks, which have created a growing concern for producers, consumers, and public health organizations regarding the safety of the products that are being produced. Water is considered one of the major routes through which pathogens can cross-contaminate produce. Hence, treating wash water with sanitizer is necessary to prevent the accumulation of pathogens during produce wash. Proper sanitation, especially during the post-harvest washing of produce, in a recirculated wash water system, such as dunk tanks, is crucial for producing safe food for consumers [17]. Chlorine-based sanitizers are deemed one of the most commonly used sanitizers in the fresh produce industry [18]. Although bleach is relatively inexpensive and can eliminate a broad range of microorganisms, it is considered highly corrosive and has a greater affinity to bind with available organic loads [17]. Consequently, maintaining an adequate concentration of free chlorine in produce wash water, especially in the presence of high organic loads, is a great challenge for the produce industry [18]. The recommended concentration for chlorine-based compounds used for rinsing produce is between the range of 50-100 ppm free chlorine [19]. Akbas and Olmez (2007) studied the effect of chlorine solution on reducing the population of E. coli and L. monocytogens on contaminated lettuce [20]. The lettuce samples were dipped in $100 \mathrm{mg} / \mathrm{L}$ of free chlorine water for 2 and $5 \mathrm{~min}$. The results indicated that the treatment resulted in 1.0 and $2.0 \mathrm{log} \mathrm{CFU} / \mathrm{g}$ reductions of the population of L. monocytogens and E. coli, respectively. Chen and Hung (2017) studied the effect of organic loads on the chlorine demand of fresh produce wash water systems on romaine lettuce. The team studied the chlorine demand of wash water with different organic load, $\mathrm{pH}$, and chlorine concentrations. The results indicated that chlorine demand significantly increased with an increase in organic load [18]. Additionally, various studies have also supported that the presence of organic matter reduces the efficacy of any chlorine-based sanitizers [21].

Similar to the above studies, bleach and Sanidate 5.0 were both capable of reducing the population of E. coli O157:H7. The 100-ppm bleach treatment in potable wash water gave 3.19 and $3.13 \log \mathrm{CFU} / \mathrm{mL}$ reductions of the pathogen at 3 and $6 \mathrm{~h}$ on the spinach leaves. In contrast, the 100-ppm bleach and phage cocktail in sterile wash water gave 5.51 and $5.32 \log$ CFU / mL reductions of the pathogen at 3 and $6 \mathrm{~h}$, respectively. The phage-bleach combination achieved $2.32 \log \mathrm{CFU} / \mathrm{mL}$ more on reducing the pathogen compared to bleach treatment alone at the end of $3 \mathrm{~h}$. The 100-ppm Sanidate 5.0 treatment in potable wash water, both in the presence or absence of the phage cocktail, led to an undetectable amount of pathogen. However, once the organic load was introduced into the wash water, both the sanitizers were severely limited in reducing the pathogen. The 100-ppm bleach and 100-ppm Sanidate 5.0 treatment in organic water had an extremely restricted effect on the pathogen's growth. Despite the presence of a high organic load, the 100-ppm bleach-phage cocktail treatment gave 3.83 and $5.30 \log \mathrm{CFU} / \mathrm{mL}$ reductions of the pathogen at 3 and $6 \mathrm{~h}$, respectively, and the 100-ppm Sanidate 5.0-phage cocktail treatment gave 3.83 and $5.27 \log \mathrm{CFU} / \mathrm{mL}$ reductions at the end of 3 and $6 \mathrm{~h}$, respectively. This corresponds to 
4.03 and $5.31 \log \mathrm{CFU} / \mathrm{mL}$ more reduction on the bleach-phage combination treatment and 3.77 and $5.17 \log \mathrm{CFU} / \mathrm{mL}$ more reduction on the Sanidate 5.0-phage combination treatment, respectively. Despite the sanitizer's presence or absence, the phage cocktail demonstrated a consistent reduction (99.96-99.99\%) of E. coli O157:H7 at 3 and 6 h. This study demonstrates the phage's ability to eliminate contamination despite being subjected to a complex wash solution.

The bacteriophage cocktail used in this study has been previously investigated for its specificity in infecting only E. coli O157:H7 strains and their ability to survive in the presence of 100-ppm bleach or Sanidate 5.0 [12,13]. The cocktail has also been studied individually without the presence of sanitizer to see its efficacy in reducing the population of E. coli O157:H7 [13]. Survival of the phage cocktail in the presence of sanitizers might open new avenues of using phage-sanitizer combinations as an effective method in eliminating select pathogens in the food industry. The emergence of phage-resistant bacterial mutants, the transduction of undesirable characteristics among bacteria, and environmental conditions are potential problems that can reduce the effectiveness of phage treatments [22]. The discovery of new phages and rotational phage applications might help prevent the formation of any phage-resistant mutants. Phages are among the most abundant microorganisms, with an estimated range of $>10^{30}$ particles found in our biosphere [23]. Phages are also found in food and water that are commonly consumed by humans [24]. For instance, phages have been isolated from various food products such as pork sausage, poultry, ground beef, freshwater fish, marine fish, oysters, cheese, and raw skim milk [25-29]. Therefore, the technique of using phages to reduce contamination in food products might be one of the most natural ways of eliminating specific pathogens. Apart from its application to food products, phages can also be used selectively for cleaning food and non-food contact surfaces and equipment naturally or in combination with sanitizers.

\section{Discussion}

Increased microbial contamination in produce has led to several foodborne outbreaks that have created a growing concern for producers, consumers, and public health organizations regarding the safety of the products that are being produced. Water is considered one of the major routes through which pathogens can cross-contaminate produce. Hence, treating wash water with sanitizer is necessary to prevent the accumulation of pathogens during produce washes. Proper sanitation, especially during post-harvest washing of produce in a recirculated wash water system such as dunk tanks, is crucial for producing safe food for consumers [17]. Chlorine-based sanitizers are deemed one of the most commonly used sanitizers in the fresh produce industry [18]. Although bleach is relatively inexpensive and can eliminate a broad range of microorganisms, it is considered highly corrosive and has a greater affinity to bind with available organic loads [17]. Consequently, maintaining an adequate concentration of free chlorine in produce wash water, especially in the presence of high organic loads, is a great challenge for the produce industry [18]. The recommended concentration for chlorine-based compounds used for rinsing produce is between the range of 50-100 ppm free chlorine [19]. Akbas and Olmez (2007) studied the effect of chlorine solutions on reducing the population of E. coli and L. monocytogens on contaminated lettuce [20]. The lettuce samples were dipped in $100 \mathrm{mg} / \mathrm{L}$ of free chlorine water for 2 and $5 \mathrm{~min}$. The results indicated that the treatment resulted in 1.0 and $2.0 \log \mathrm{CFU} / \mathrm{g}$ reductions of the populations of L. monocytogens and E. coli, respectively. Chen and Hung (2017) studied the effect of organic loads on the chlorine demand of fresh produce wash water systems on romaine lettuce. The team studied the chlorine demand of wash water with different organic load, $\mathrm{pH}$, and chlorine concentrations. The results indicated that chlorine demand significantly increased with an increase in organic load [18]. Additionally, various studies have also supported that the presence of organic matter reduces the efficacy of any chlorine-based sanitizers [21].

Similar to the above studies, bleach and Sanidate 5.0 were both capable of reducing the population of E. coli O157:H7. The 100-ppm bleach treatment in potable wash water 
gave 3.19 and $3.13 \log \mathrm{CFU} / \mathrm{mL}$ reductions of the pathogen at 3 and $6 \mathrm{~h}$ on the spinach leaves. In contrast, the 100-ppm bleach and phage cocktail in sterile wash water gave 5.51 and $5.32 \log \mathrm{CFU} / \mathrm{mL}$ reductions of the pathogen at 3 and $6 \mathrm{~h}$, respectively. The phage-bleach combination achieved $2.32 \log \mathrm{CFU} / \mathrm{mL}$ more reduction of the pathogen compared to bleach treatment alone at the end of $3 \mathrm{~h}$. The 100-ppm Sanidate 5.0 treatment in potable wash water, both in the presence or absence of the phage cocktail, led to an undetectable amount of pathogen. However, once the organic load was introduced into the wash water, both the sanitizers were severely limited in reducing the pathogen. The 100-ppm bleach and 100-ppm Sanidate 5.0 treatment in organic water had an extremely restricted effect on the pathogen's growth. Despite the presence of a high organic load, the 100-ppm bleach-phage cocktail treatment gave 3.83 and $5.30 \log \mathrm{CFU} / \mathrm{mL}$ reductions of the pathogen at 3 and $6 \mathrm{~h}$, respectively, and the 100-ppm Sanidate 5.0-phage cocktail treatment gave 3.83 and $5.27 \log \mathrm{CFU} / \mathrm{mL}$ reductions at the end of 3 and $6 \mathrm{~h}$, respectively. This corresponds to 4.03 and $5.31 \log \mathrm{CFU} / \mathrm{mL}$ more reduction from the bleach-phage combination treatment and 3.77 and $5.17 \log \mathrm{CFU} / \mathrm{mL}$ more reduction from the Sanidate 5.0-phage combination treatment, respectively. Despite the sanitizer's presence or absence, the phage cocktail demonstrated a consistent reduction (99.96-99.99\%) of E. coli O157:H7 at 3 and $6 \mathrm{~h}$. This study demonstrates the phage's ability to eliminate contamination despite being subjected to a complex wash solution.

The bacteriophage cocktail used in this study has been previously investigated for its specificity in infecting only E. coli O157:H7 strains and their ability to survive in the presence of 100-ppm bleach or Sanidate 5.0 [12,13]. The cocktail has also been studied individually without the presence of sanitizer to see its efficacy in reducing the population of $E$. coli O157:H7 [13]. Survival of the phage cocktail in the presence of sanitizers might open new avenues of using phage-sanitizer combinations as an effective method in eliminating select pathogens in the food industry. The emergence of phage-resistant bacterial mutants, the transduction of undesirable characteristics among bacteria, and environmental conditions are potential problems that can reduce the effectiveness of phage treatment [22]. The discovery of new phages and rotational phage applications might help prevent the formation of any phage-resistant mutants. Phages are among the most abundant microorganisms, with an estimated range of $>10^{30}$ particles found in our biosphere [23]. Phages are also found in food and water that are commonly consumed by humans [24]. For instance, phages have been isolated from various food products such as pork sausage, poultry, ground beef, freshwater fish, marine fish, oysters, cheese, and raw skim milk [25-29]. Therefore, the technique of using phages to reduce the contamination of food products might be one of the most natural ways of eliminating specific pathogens. Apart from its application on food products, phages can also be used selectively for cleaning food and non-food contact surfaces and equipment naturally or in combination with sanitizers.

\section{Conclusions}

Developing a novel technique and frequently updating sanitation methods are necessary for controlling pathogens and preventing the occurrence of foodborne outbreaks. The data presented in these studies suggest that a phage-based approach might act as a hurdle technology to help prevent disease caused by foodborne bacteria such as E. coli O157:H7. The produce wash study proved their effectiveness in reducing contamination in both the presence and absence of sanitizer, even when subjected to a complex wash system containing a high organic load. These studies indicate that bacteriophages can be effectively used in reducing E. coli O157:H7 contamination on fresh produce that is exclusively washed in dunk tanks. It is possible that with further optimization of the dosage, delivery mechanism, and formulation, the effectiveness of phages can be further improved in specifically reducing E. coli O157:H7 contamination on fresh produce. The ability of phages to selectively infect bacteria can be utilized to formulate cocktails that can then be selectively used against pathogens or spoilage microorganisms, depending 
on the type of food product. A bacteriophage biocontrol strategy would be an acceptable technique and a natural alternative to food safety and preservation.

Author Contributions: Conceptualization, B.V.J., P.P.V. and M.M.; Data curation, B.V.J.; Formal analysis, B.V.J.; Investigation, B.V.J., P.P.V. and M.M.; Resources, P.P.V., S.K., S.P. and M.M.; Supervision, P.P.V. and M.M.; writing—original draft, B.V.J.; writing—review and editing, P.P.V., S.K., S.P. and M.M. All authors have read and agreed to the published version of the manuscript.

Funding: This research received no external funding.

Institutional Review Board Statement: Not applicable.

Informed Consent Statement: Not applicable.

Data Availability Statement: Data are contained within the article.

Acknowledgments: The authors would like to thank Kelsey Lamb, Mari Schroeder, and Noel Kubat for the continuous support that they have provided in the lab and thank Matthew Rutledge, Eva Loveland, Aviv Brokman, and the Applied Statistics Lab at the University of Kentucky for their help with statistical analysis.

Conflicts of Interest: The authors declare no conflict of interest.

\section{References}

1. Callejón, R.M.; Rodriguez-Naranjo, M.I.; Ubeda, C.; Hornedo-Ortega, R.; Garcia-Parrilla, M.C.; Troncoso, A.M. Reported foodborne outbreaks due to fresh produce in the United States and European Union: Trends and causes. Foodborne Pathog. Dis. 2015, 12, 32-38. [CrossRef]

2. Nüesch-Inderbinen, M.; Stephan, R. Fresh fruit and vegetables as vehicles of bacterial foodborne disease: A review and analysis of outbreaks registered by proMED-mail associated with fresh produce. Arch. Für Lebensm. (J. Food Saf. Food Qual.) 2016, 67, 32-39.

3. Feliziani, E.; Lichter, A.; Smilanick, J.L.; Ippolito, A. Disinfecting agents for controlling fruit and vegetable diseases after harvest. Postharvest Biol. Technol. 2016, 122, 53-69. [CrossRef]

4. Center for Disease Control and Prevention. List of Selected Multistate Foodborne Outbreak Investigations. Available online: https://www.cdc.gov / foodsafety / outbreaks/multistate-outbreaks/outbreaks-list.html (accessed on 11 February 2020).

5. Sapers, G.M. Efficacy of washing and sanitizing methods for disinfection of fresh fruit and vegetable products. Food Technol. Biotechnol. 2001, 39, 305-311.

6. Gómez-López, V.M. Decontamination of Fresh and Minimally Processed Produce; Wiley-Blackwell: Hoboken, NJ, USA, 2012.

7. Higgins, G. Infiltration. Available online: https://ag.umass.edu/vegetable/fact-sheets/infiltration (accessed on 16 February 2018).

8. Van Haute, S.; Luo, Y.; Sampers, I.; Mei, L.; Teng, Z.; Zhou, B.; Bornhorst, E.; Wang, Q.; Millner, P. Can UV absorbance rapidly estimate the chlorine demand in wash water during fresh-cut produce washing processes? Postharvest Biol. Technol. 2018, 142, 19-27. [CrossRef]

9. Jagannathan, B.V.; Vijayakumar, P.P. The need for prevention-based food safety programs for fresh produce. Food Prot. Trends 2019, 39, 572-579.

10. Barrera, M.; Blenkinsop, R.; Warriner, K. The effect of different processing parameters on the efficacy of commercial post-harvest washing of minimally processed spinach and shredded lettuce. Food Control 2012, 25, 745-751. [CrossRef]

11. Gombas, D.; Luo, Y.; Brennan, J.; Shergill, G.; Petran, R.; Walsh, R.; Hau, H.; Khurana, K.; Zomorodi, B.; Rosen, J. Guidelines to validate control of cross-contamination during washing of fresh-cut leafy vegetables. J. Food Prot. 2017, 80, 312-330. [CrossRef]

12. Vengarai Jagannathan, B.; Kitchens, S.; Vijayakumar, P.P.; Price, S.; Morgan, M. Potential for bacteriophage cocktail to complement commercial sanitizer use on produce against Escherichia coli O157:H7. Microorganisms 2020, 8, 1316. [CrossRef]

13. Vengarai Jagannathan, B.; Kitchens, S.; Priyesh Vijayakumar, P.; Price, S.; Morgan, M. Efficacy of bacteriophage cocktail to control E. coli O157: H7 contamination on baby spinach leaves in the presence or absence of organic Load. Microorganisms 2021, 9, 544. [CrossRef] [PubMed]

14. Bates, D.; Mächler, M.; Bolker, B.; Walker, S. Fitting linear mixed-effects models using lme4. arXiv 2014, arXiv:1406.5823.

15. Kunzetsova, A.; Brockhoff, P.; Christensen, R. lmerTest package: Tests in linear mixed effect models. J. Stat. Softw. 2017, 82, 1-26.

16. Lenth, R.; Singmann, H.; Love, J.; Buerkner, P.; Herve, M. emmeans: Estimated marginal means. R package version 1.4. 4. Am. Stat. 2020, 34, 216-221.

17. Sargent, S.A.; Ritenour, M.; Brecht, J.; Bartz, J. Handling, cooling and sanitation techniques for maintaining postharvest quality. EDIS 2000, 3, 1-11.

18. Chen, X.; Hung, Y.-C. Effects of organic load, sanitizer $\mathrm{pH}$ and initial chlorine concentration of chlorine-based sanitizers on chlorine demand of fresh produce wash waters. Food Control 2017, 77, 96-101. [CrossRef] 
19. World Health Organization. Microbiological Hazards in Fresh Leafy Vegetables and Herbs. Meeting Report. Available online: http:/ / www.fao.org/3/a-i0452e.pdf (accessed on 12 December 2019).

20. Akbas, M.Y.; Ölmez, H. Inactivation of Escherichia coli and Listeria monocytogenes on iceberg lettuce by dip wash treatments with organic acids. Lett. Appl. Microbiol. 2007, 44, 619-624. [CrossRef]

21. Park, E.-J.; Alexander, E.; Taylor, G.A.; Costa, R.; Kang, D.-H. The decontaminative effects of acidic electrolyzed water for Escherichia coli O157:H7, Salmonella typhimurium, and Listeria monocytogenes on green onions and tomatoes with differing organic demands. Food Microbiol. 2009, 26, 386-390. [CrossRef]

22. Vidaver, A.K. Prospects for control of phytopathogenic bacteria by bacteriophages and bacteriocins. Annu. Rev. Phytopathol. 1976, 14, 451-465. [CrossRef]

23. Brüssow, H.; Hendrix, R.W. Phage Genomics: Small Is Beautiful. Cell 2002, 108, 13-16. [CrossRef]

24. Abuladze, T.; Li, M.; Menetrez, M.Y.; Dean, T.; Senecal, A.; Sulakvelidze, A. Bacteriophages reduce experimental contamination of hard surfaces, tomato, spinach, broccoli, and ground beef by Escherichia coli O157:H7. Appl. Environ. Microbiol. 2008, 74, 6230. [CrossRef]

25. Atterbury, R.J.; Connerton, P.L.; Dodd, C.E.; Rees, C.E.; Connerton, I.F. Isolation and characterization of Campylobacter bacteriophages from retail poultry. Appl. Environ. Microbiol. 2003, 69, 4511-4518. [CrossRef]

26. Gautier, M.; Rouault, A.; Sommer, P.; Briandet, R. Occurrence of Propionibacterium freudenreichii bacteriophages in swiss cheese. Appl. Environ. Microbiol. 1995, 61, 2572-2576. [CrossRef] [PubMed]

27. Kennedy, J.E., Jr.; Oblinger, J.L.; Bitton, G. Recovery of coliphages from chicken, pork sausage and delicatessen meats. J. Food Prot. 1984, 47, 623-626. [CrossRef] [PubMed]

28. Kennedy, J.E., Jr.; Wei, C.I.; Oblinger, J.L. Methodology for enumeration of coliphages in foods. Appl. Environ. Microbiol. 1986, 51, 956-962. [CrossRef]

29. Whitman, P.A.; Marshall, R.T. Isolation of psychrophilic bacteriophage-host systems from refrigerated food products. Appl. Microbiol. 1971, 22, 220-223. [CrossRef] [PubMed] 